\title{
Fostering employee loyalty: role of empowerment leadership, trust, commitment and satisfaction
}

\author{
Quang Van Ngo \\ Faculty of Business Management, \\ Hanoi University of Industry, \\ Vietnam \\ Email: quangnv@haui.edu.vn
}

\author{
Luan Ngoc Trinh \\ Faculty of Business Management, \\ Hanoi University of Industry, \\ Vietnam \\ Email: ngocluanqtkd1@gmail.com
}

\author{
Chung Xuan-Thi Nguyen \\ Business School, Hunan University, \\ Changsha, Hunan, PR China \\ Email: \\ nguyenxuanthichung22091995@gmail.com
}

\begin{abstract}
Recently, the employee loyalty is among the most important issues for the firms, especially in the context of Covid-19 that cause a lot of serious problems for all society and firms. The main aim of this research is to link the empowerment leadership and employee loyalty with the mediating effects of employee trust, commitment and satisfaction. To reach the end, this research applied both qualitative and quantitative method in the context of market officer from animal feed products in Thanh Hoa, Vietnam. Finally, 220 valid questionnaires collected via a questionnaire survey were analyzed applying structural equation modelling with Amos software. The results showed that empowerment leadership has a strong influence on employee loan this research Itd. Moreover, this leadership style stimulates employee trust, commitment and satisfaction. Besides, employee commitment has a positive effect on employee loyalty.
\end{abstract}

Index Terms-Empowerment leadership, employee behavior, employee loyalty, employee commitment, employee satisfaction

\section{INTRODUCTION}

$\mathrm{M}$ ANAGEMENT, after all, is the management of people because the success or failure of a firm depends greatly on the human factor, and people are the subject of all activities in the firm. Therefore, business administration is considered as science and art in using human resources. However, there are many businesses that are still limited in human resource management, so they have not fully exploited the capacity of employees. There are many factors that influence this issue and leadership style is one of them.

Previous studies have shown that leaders play a very important role in bonding, promoting loyalty and willingness to devote, stick with, and awaken the potential of employees. Besides, leaders build a strong team together and stimulate subordinates to trust each other when they are facilitated to gain more rights [1]. These studies highlight the role of internal marketing in businesses, that is, businesses not only satisfy external customers but also internal customers - employees to promote positive behaviors of employees[2].

Many studies have shown that the empowerment leadership style enhances the meaning of work, provides employees with autonomy and self-determination, demonstrates the manager's belief in the employee's motivation and makes a difference in job results by promoting the conscious influence of subordinates [3]. When trusted to empower, employees are willing to put more effort into innovation, demonstrate a greater desire to engage in creative activities, create engagement, and influence loyalty to the official organization and managers. While the empowerment leadership style has been recognized to have an impact and influence on employee loyalty. However, through literature review, this relationship has not been fully studied, explored and analyzed. Therefore, previous scholars pointed out that it is necessary to further study this relationship by adding mediating variables in order to better clarify the mechanism of the empowerment leadership style [4].

A trust relationship between the leader and the subordinates could be another factor in the link between anti-corruption and employee loyalty[5]. From an emotional point of view, employees are more willing to reach their full potential and stay engaged for the long term when they are empowered by leaders they trust[6]. When employees have confidence in their leaders, they benefit from an increased relationship between the empowerment leadership style and their loyalty as well as a decrease in employee turnover [7]. Thus, the influence of the empowerment leadership style on employee loyalty can be mediated by trust, commitment and satisfaction in the leader.

The empowerment leadership style plays a particularly important role in employee loyalty under certain conditions, especially in the context of Vietnam's deep economic integration in the region and globally with challenges and changes. The current complicated economic situation before the impact of the Covid 19 pandemic, when the freedom of movement, travel and direct negotiations have certain limitations. In particular, when employees leave their jobs and move to rival companies, it will cause confusion and increase the risk for businesses in terms of know-how and data[8].

From the recommendations and research gaps of previous studies, along with the current context and situation in Vietnam, production and business activities in general, the agricultural sector, and more specifically in the field of livestock, farming industry in particular is facing difficulties and challenges: The complicated and unpredictable developments of the COVID-19 pandemic affect domestic consumption and production markets, the supply of raw materials for the food industry. Livestock consumption fluctuates, many agricultural product import markets tighten technical barriers and trade safeguard measures. The author understands the great importance and power of human resources in the organization, in the face of demands that always have to be mobilized and changed to match trends in the new era, cohesion and loyalty. The success of market staff clinging to the area is a matter of survival for businesses in the feed industry today. Therefore, this research wishes to clarify the 
impact of anti-trafficking on the loyalty of market employees of firms in the feed industry as well as to clarify the relationship between them. Specifically, this research will answer the following questions:

Question 1: How does the empowerment leadership style affect employee loyalty?

Question 2: What is the role of employee trust, commitment, and employee satisfaction in the relationship between the empowerment of leadership and employee loyalty?

Question 3: What solutions should leaders of businesses in the feed industry in Vietnam have to improve employee loyalty?

\section{BACKgrounded Theories}

\section{A. Employee loyalty}

Loyalty was originally understood as an employee's feeling of attachment to the organization, according to [9] [10]define: "Loyalty is the active expression of pride and commitment to the organization". [11] argues that "loyalty is sometimes used as a synonym for one or more forms of commitment". To [12], "Loyalty means that employees stick with someone or something even if it goes against personal interests". Final statement "Employee loyalty is the willingness to work on behalf of the organization, for its goals and values to be aligned with the organization, and the desire to remain a member of the organization."[11].

Willingness to resist criticisms, limitations, and complaints about the organization and to emphasize the positive aspects of an organization are fundamental expressions of loyalty. When employees commit themselves to the success of the organization and accept to believe that working for this organization is their best choice, it shows that they are completely loyal to the organization[13]. Employee loyalty is reflected in the fact that they stay with the organization: "the intention or desire to remain a member of the organization"[14]. Mowday's well-known definition of loyalty is similar to the Aon Consulting Institute's national concept of "retention" for many years: "Employees intend to stay with the organization despite having relatively more attractive salary offers elsewhere. Loyalty measures the following criteria: Willingness to recommend his company as a good place to work; willingness to recommend the company's products and services; willingness to stay with the company for a long time. There are many authors in the world and in Vietnam who have researched on the factors affecting employee loyalty. Specifically, [15] researched on: "The study of employee satisfaction and its effects towards loyalty in the hotel industry in Klang Valley, Malaysia". From there, we identify certain factors that affect employee loyalty to the organization, including: Nature of work, income and benefits, working conditions, leadership, work motivation employment, training and development, peer relationships. However, because of different occupations and different levels of workers, the above factors may vary to certain extents.

\section{B. Empowerment Leadership and the Role of Empowerment Leadership}

Leadership style is a leader's method and approach to set directions, implementing plans, and motivating employees. From an employee's point of view, that style is often ex- pressed in actions either explicitly or implicitly from their leader [16]. The empowerment of leadership can be understood by many scholars as a process of sharing power and allocating autonomy and responsibility to followers, groups or collectives through a specific set of behaviors by the leader for the loyal group to enhance internal motivation and achieve success at work [17]. Above all, the concept of leadership empowerment enhances the meaning of work, gives employees autonomy and self-determination, demonstrates the manager's belief in the employee's ability to promote a sense of subordinates, and improves job performance. Since then, the benefits of leadership empowerment are often claimed to be most beneficial, humanity, and ethical.

The goal of developing the "self-leadership" of subordinates is a matter of focused leadership style. In this leadership style, employees are encouraged to act in their own way to make decisions. Leaders play a role in promoting self-discipline, stimulating interest and motivation at work, and assisting in enhancing the improvement of employees' constructive thinking habits. A new approach is the emphasis on assigning responsibilities to subordinates to help leaders streamline the distribution and exercise of power in the act of empowerment. When employees are empowered, they spend more time and effort than usual to solve problems encountered at work. Compared with their unempowered colleagues, they are more likely to generate new and useful ideas. Thus, sharing power and providing autonomy when necessary helps to activate the internal force that exists within subordinates, who are willing to put more effort into engaging in creative behaviors that create innovation.

\section{Motivational theories}

\section{1) Relationship Marketing}

There is evidence to support the effectiveness of trust in relationship marketing [18-20]. This trust is expressed in relationships, which have many different types of outcomes including qualitative and quantitative such as: increased satisfaction about the partnership[21], reduced dangerous disputes between parties[22], increasing the quality of information gathered for the parties[23], increasing the commitment of the parties[24, 25], strengthen cooperation between partners[26], reduce project completion time[27]. The importance of relationship marketing between large and small businesses when raising capital is similar to that of every connector in a vertical company[28].

According to the American Marketing Association AMA, relationship marketing is a marketing activity to create and maintain long-term relationships between businesses and partners (especially customers) in order to successfully achieve business goals... From a management point of view, relationship marketing is a marketing activity that builds, maintains and strengthens the relationship between superiors and employees. Employees, customers, managers and leaders are all the same because just satisfying the necessary needs will improve their feedback to the workplace. When an employee is satisfied with his boss, working environment, and benefits, the employee's ability to devote himself to his work to contribute to the company is very high. Empowerment leadership style helps employees and leaders to build relationships that focus on long-term interests with the company's common goals as the basis, the organization will 
retain talented employees and improve managerial apparatus.

According to Lowe, "Relationship marketing includes all marketing activities aimed at establishing, developing, and maintaining successful relationship exchanges" (Lowe 2019). In this theory, trust and commitment are built from: the costs of ending the relationship, the benefits from the relationship, shared values, information exchange, and opportunistic behavior.

Sujan Patel found that besides creating a favorable environment, it will help innovations to be born and shorten the communication distance between people. Technology also has a downside that is losing the privacy of users. Empowerment leadership helps employees take responsibility for their decisions and not interfere in their work [29].

\section{2) Theory of trust-commitment}

The theory of trust-commitment provides a theoretical framework for building trust and commitment in boss-employee relationships $[25,30]$. In the long-term relationship between the parties, power is considered the fundamental concept. However, at least one-third of power-based relationships break down[31]. Organizational commitment is the degree to which employees believe and accept the goals of an employee with the desire to work for the organization[32]. Therefore, Morgan \& Hunt believe that the element of commitment and trust will help increase the effectiveness in a relationship, which is very consistent with the relationship between empowerment leadership style and employee loyalty. [25].

The belief-commitment theory first appeared in Becker's word "a mechanism that induces appropriate human behavior" [33]. The concept of employee commitment attitude towards the organization as a whole is explained by Halawi (2005) as "the power to identify an individual participating in a particular organization" [34]. Commitment is expressed as a psychological state when formed after an individual's relationship with an organization is the behavior of employees deciding to stay or leave the organization [35]. The higher the employee's commitment, the easier it is to grasp the organization's goals and values; they are willing to work for the success of the organization; they have a constant desire to stay in the organization [36]. In addition, according to Morgan \& Hunt, commitment refers to the trust between two parties in a long-term relationship, it is so important that it takes continuous maximum efforts to maintain. This is essential for long-term relationships between partners [37], leading to a special emotional motivation between employees and the company when actively participating in the activities. joint activities [38].

Trust manifests itself in three aspects: ability, benevolence, and integrity [35]. The person has the ability to be completely committed; a conscientious person who cares about the interests of the partner; Honest people know exactly what is going on from their side to the other side [39].

\section{3) Maslow's Hierarchy of Needs}

The theory of psychology and human motivation has a famous model that is Maslow's hierarchy of needs in the article "A Theory of Human Motivation" from 1943. With 5 levels of human needs with 5 levels respectively., in which, each floor reflects a different level of complexity and the higher up, the more human needs increase. Maslow's Hierarchy of Needs explains people's behaviors without being aware of it themselves. Therefore, the meaning of Maslow's pyramid is applied in many areas of life such as business, administration, education... especially in the field of human resource management. Here are the 5 levels of Maslow's hierarchy of needs:

- Physiological needs

At the bottom of the pyramid are physiological needs, which are the most basic needs of a human being. This need is needed for basic human survival such as food, food, health, shelter, air, water, sleep, etc. The human body cannot sustain life if these needs are met. Unsatisfied. These are considered the most important, so they must be met first and foremost.

- The safety needs

When basic physiological needs are satisfied, people will prioritize their own safety. Those needs include physical safety, health, safety in the family, finances or employment...

- Societal needs

Once physiological and safety needs are fulfilled, the need for emotional communication will focus people's attention more than ever. They can become lonely, anxious and even depressed if they do not love and be loved. Because people always want to integrate into a certain community, want a happy family, have close friends.

- The esteem needs

Everyone has a need for self-esteem and stable self-esteem. They gain respect, which can be done through a sense of self-esteem, respect for others, strength, competence, proficiency, confidence, independence, and freedom.

- The self-actualization needs

The basis for the perceived need for self-actualization is satisfactorily met after previous needs have been met. People began to focus on realizing their potential. In the hierarchy of needs, Maslow describes, "people want to achieve all that is in their ability, to be on top and constantly improve to become the best version of themselves."

Applying Maslow's pyramid to work and life is quite simple because each needed milestone has its own. However, in the field of human resource management, taking people as the root of the problem, every employee will have all 5 needs at the same time. Therefore, it is very important for the empowerment house to offer appropriate policies for each individual at different times. The same policy cannot be applied to many people, nor can the same policy apply to one person forever because they will have different needs.

\section{4) Expectation theory}

Vroom's expectancy theory explains why people are motivated to strive for perfection. Vroom's expectancy theory is the most commonly applied theory of all motivational theories.

Vroom explains that an individual's motivation and work behavior is determined by their perception of what they will achieve in the future when trying to work.

People will try to work if they know that this will bring them good results or rewards of great value to them. For example, a person has a goal to advance at work and they perceive that their dedication will bring them achievements, 
these achievements will help them achieve their promotion goals, then the perception will motivate them to work hard to achieve their own aspirations.

Employees will decide on a certain amount of effort to be able to achieve the goals of the firm. It also depends on the results, expectations and prizes they think they will get or how important that award is to them.

The formula for determining personal motivation according to Vroom is the product of work motivation, expectations, and the probability that an individual assigns the level of effort they put in to achieve the expected level of performance.

From the above formula, it can be seen that the theory of expectation is the theory that revolves around three relationships between expected dynamics and probability.

\section{Research Model}

The leadership style of the administrator is considered as one of the important factors in the development of the firm as well as determining the attachment and loyalty to the organization of employees. Many studies have proven that if managers practice the ideal leadership style, it will create an important motivation for the increase in employee loyalty. Among them, there have also been scholars who have conducted research on the relationship between the empowerment of leadership and employee loyalty. For example, [10] surveys on a small scale demonstrated that empowerment leadership indirectly affects employee loyalty. In another study by [2]in the banking sector, it was also demonstrated that leadership empowerment is a key factor promoting employee loyalty to the organization they serve.

From there, this research proposes the following hypothesis:

H1: Empowerment leadership style has a positive effect on employee loyalty.

In corporate culture or in life, trust is the foundation for success. However, the tendency of employees and leaders to trust each other less often leads to adversarial relationships that deviate from the reality of low performance. While the potential motivation of employees is influenced by their superiors [40], the employee empowerment style of the leaders. bring high efficiency in terms of work feasibility, change and improve relationships, resolve internal conflicts, consider the level nature of leadership [41] thereby enhancing confidence in a manager who is both competent and ethical. In addition, empowerment leadership facilitates the development of trust in leadership through behaviors such as demonstrating trust in authority at all levels. When employees feel supported by leaders at all levels, relationships are created and maintained in a holistic context, and trust in leadership is fostered progressively [42]. Leadership empowerment behaviors also have a strong impact on employees' attitudes, beliefs, intentions, and behaviors [43].

The mediating role of employee trust appears in the relationship between leadership and employee performance [44]. Empowerment leadership style has a positive effect on subordinates' trust in leaders. Belief in leadership increases the effectiveness of the empowerment leadership style. According to the research, [45] also confirmed that employee's beliefs play a mediating role in influencing leadership ability.

Proposed hypothesis H2:

H2: Empowerment leadership style affects employees' belief in leadership.

Once employees trust the leader and the decisions they make about the direction and common goals, the employee's loyalty to the organization increases. The mediating role of multidimensional beliefs associated with cognitive support also influences employee loyalty characteristics [46].

Proposed hypothesis H3:

H3: Employee trust affects employee loyalty.

Kevin Kruse refers to the definition of commitment: "It is an employee's emotional commitment to an organization and its goals". Style or personality represents the difference between committed and uncommitted employees, they are based on decisions rooted in loyalty and commitment to all levels of the company. The level of employee commitment is considered a fundamental factor for achieving better performance in any organization. Research by [47] also shows that empowerment leader behaviors at one point in time is positively related to estimates of employee commitment and will be more committed to the organization. Structuring for organizational commitment takes place, leaders propose to create structurally empowerment work environments that support a stronger employee commitment to the organization[48]. Engagement in the workplace through empowerment of employees towards results-oriented commitments and strategically empowerment predecessor levels of commitment is also geared toward individual results [49]. Is the implementation of the empowerment leadership affected by the employee's commitment to the organization?

When there are talented leaders, they know how to create an effective working environment so that employees can actively apply, promote and improve their own abilities, and the loyalty of subordinates is shown. Above all, respect and admiration must be from both sides to make this relationship a lasting bond. Another study demonstrated that the mediating role of job satisfaction affects the relationship between employee commitment and their loyalty [50]. In addition, mediating the basis of employee loyalty strongly influences human resource practices, as different resources engage and retain employees [51] will have an effect. significant impact on the transformation of an organization's resources. In summary, employee commitment plays an important role, acting as a mediating bridge in the orientation of labor prevention, favoring the form of empowerment for employees from the leader and towards the common goal of improving employee satisfaction. employee loyalty to the organization.

Therefore, this research builds two hypotheses H4, H5:

H4: Empowerment leadership style affects employee commitment.

H5: Employee commitment affects employee loyalty.

Originating from motivation theory and organizational psychology, "job satisfaction is the sum of psychological, physiological and environmental factors that make a person feel satisfied with his or her job. them" [51] or "is the feeling that employees feel about their work" [52] or "attitudes about work are expressed by feelings about the beliefs and behaviors of employees." workers" [53]. The classical the- 
ory of job satisfaction is divided into three main groups[54]: Maslow's Needs Scale (1943) and F. Herzberg's two-factor theory (1950) are classic theories that say that "meeting the job full of needs that will satisfy employees' work"; Vroom's theory says that "job satisfaction is the impact of three relationships: expectations, values, and wants, and context theory says that job satisfaction has the impact of three factors. factors: individual, work and organization".

With any organization, businesses need to achieve when encouraging employees to work long-term with the firm and devote themselves with their capacity, ability and enthusiasm to achieve the common goalsof theorganization. That is to get the loyalty of employees. From the manager's perspective, job satisfaction needs to be seen as a guiding factor to help employees work better. That is the degree to which they have a positive perception and orientation towards employment in the organization. Therefore, organizations need to link rewards to performance and ensure that it is rewarding and meets the needs of employees. Vroom believes that "the reward will be worthy for the efforts that the achievement brings results, which is what people always expect or expect. They believe that the more effort, the higher the work efficiency, the higher the work efficiency will give rewards, such as salary increases or benefits, ...". This will satisfy the necessary needs of the workers because when the desire to satisfy the needs will be strong enough, they will make remarkable efforts. In a New York Times survey of business satisfaction, only $4 \%$ of employees are expected to leave the company within a year; $27 \%$ of them say they will leave within a year when they feel unhappy. In fact, there is a relationship between employee satisfaction and loyalty: The level of employee satisfaction affects the employee's decision to leave or stay in a firm. This result has been published and tested in studies by Aon Consulting institute in the US, Canada, UK and in Australia. With the application of Maslow's theory of needs flexibly to the conditions of the modern economy, it is said that in order to improve employee loyalty to the organization, it is necessary to satisfy their needs. Therefore, the author hypothesizes H7:

H6: Empowerment leadership style has a positive impact on employee satisfaction.

H7: Employee satisfaction has a positive impact on employee loyalty.

From the above hypotheses, the research model is described as follows:

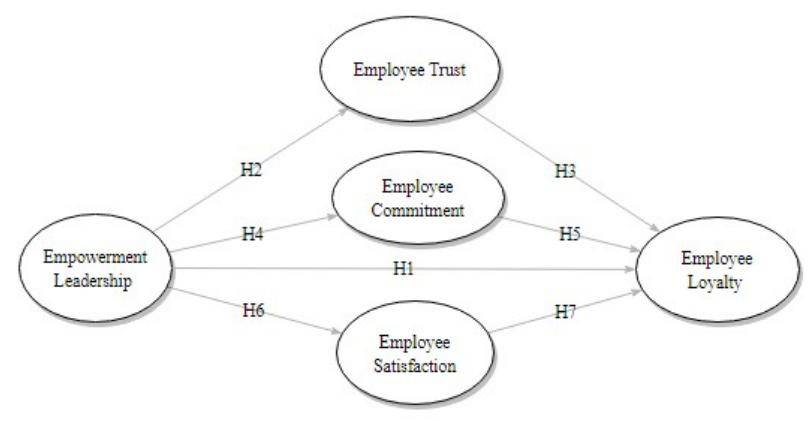

IV. Methodology

The research was carried out in Vietnam, Thanhhoa through two phases: Phase one is qualitative research through in-depth interview techniques and group discussions with marketing lecturers, collaborators, staff/marketers. , regional head/regional supervisor working for businesses in the feed industry in Vietnam, Thanhhoa province. On that basis, the author uses the discussed contents and results to adjust the observed variables, construct the questionnaire and complete the official survey for the study. Phase two carried out formal research using quantitative research methods by distributing about 200 survey questionnaires to market staff. This research is used to test the measurement model as well as the theoretical model and the hypotheses in the model.

\section{A. Qualitative research methods}

Conduct research through focus group discussion techniques to discover, as well as confirm, adjust and supplement necessary contents to develop anti-corruption scale and employee loyalty scale. This research is carried out through group discussion by group discussion outline: 3 people, 5 people or 10 people (they are individuals or businesses in the field of feed in Thanhhoa province such as lecturers) on marketing, collaborators, staff/marketers, area heads/regional supervisors...). The qualitative research results further clarified the purpose to ensure that the concepts are measured thoroughly and adequate and consistent with the characteristics of the livestock industry in Thanhhoa. From there, through the opinions of the staff, the model that affects the empowerment of leadership on employee loyalty will be selected with the most important and influential factors.

Finally, 5 factors affecting the research on empowerment leadership affecting employee loyalty are empowerment leadership, employee loyalty, employee trust, employee commitment, employee satisfaction.

\section{B. Quantitative research methods}

\section{1) Design of research variables and scales}

The empowerment of leadership is defined as a process of transferring leadership responsibility and autonomy to subordinates and sharing leadership with them, this process helps to increase the internal motivation of employees by using a variety of strategies leadership behavior (Sharma and Kirkman 2015). The empowerment leadership scale is measured by 5 observed variables . One of the observed variables is "I am empowered to solve arising problems of customers (caring, monitoring needs, handling complaints of customers). customers, negotiate with customers...)."

Employee loyalty is understood as employee feeling attached to the organization, the loyalty scale is measured by 5 observed variables and one of the typical variables is "I will always stay at the company and contribute to the company". company, even if the company has difficulties."

Employee trust is explained as employees' trust in their leaders, they feel comfortable sharing and communicating with their leaders. This scale is measured by 12 observed variables, one of which is "I can talk freely about the difficulties I face at work with the leader and I know that he/she wants to listen to me."

An employee's emotional commitment to an organization and its goals. Employee commitment is considered a fundamental factor for achieving better performance in any organization. The commitment scale is measured by 6 factors, "I 
understand and commit to the core values of the company." is one of those variables.

Derived from motivation theory and organizational psychology, job satisfaction is defined as "the sum of psychological, physiological and environmental factors that make a person feel satisfied. about their work" [51] or "is the feeling that employees feel about their work" [52] or "attitude about work is expressed by feeling about the and worker behavior" [53]. "I am satisfied with my current job." is one of 12 observed variables of the satisfaction scale.

2) Preliminary research

Quantitative preliminary research with the number of $n=100$ to preliminary evaluate the scale of variables after measuring the official research was carried out by quantitative method through survey questionnaires, distributed survey questionnaires. Official monitoring designed on Google Drive over the Internet. The expected number of direct survey participants for formal quantitative research is $n=200$, i.e. 200 collaborators, staff/marketers, area heads/regional supervisors, working area directors at firms in the field of feed in Thanhhoa province. The formal study was conducted in July, August 2021.

Quantitative research aims to test the scales and theoretical models. The authors use SPSS 20.0 software to test the scale through Cronbach's Alpha index and analyze the linear structural model SEM to further test the rigor of the model and research hypothesis.

\section{Research Results}

To test the reliability of the scale, the research uses Cronbach's alpha $(\mathrm{C} \alpha)$, the observations with confidence greater than 0.6 will be kept, if the reliability is less than 0.6 will be removed by the author from the scale.

The results of the reliability coefficient test are performed with each component in the scale. The specific results of the Cronbach's Alpha reliability test are summarized in the table below:

\begin{tabular}{|l|l|}
\multicolumn{2}{|c|}{ TABLE 1. SUMmary OF RELIABILITY ANALYSIS RESULtS } \\
\begin{tabular}{|l|l|}
\hline \multicolumn{1}{|c|}{ Variable symbol } & Cronbach's Alpha \\
\hline Empowerment Leadership & 0.870 \\
\hline Employee Loyalty & 0.893 \\
\hline Employee trust & 0.955 \\
\hline Employee Commitment & 0.971 \\
\hline Employee Satisfaction & 0.897 \\
\hline
\end{tabular}
\end{tabular}

From the above table, it can be seen that garbage variables have been eliminated, and all observations have a confidence coefficient above 0.6. In summary, with the results shown in Table 1, these scales all meet the requirements.

Table 2 Summary of Statistical indicators of the SCAle

\begin{tabular}{|lcccccccc|}
\hline & CR & AVE & MSV & Pcld & Ntld & Cknv & Hlnv & Ltt \\
\hline Pcld & 0.874 & 0.581 & 0.384 & $\mathbf{0 . 7 6 2}$ & & & & \\
\hline Ntld & 0.953 & 0.648 & 0.388 & 0.530 & $\mathbf{0 . 8 0 5}$ & & & \\
\hline Cknv & 0.968 & .836 & 0.388 & 0.578 & 0.623 & $\mathbf{0 . 9 1 4}$ & & \\
\hline HInv & 0.880 & 0.554 & 0.383 & 0.523 & 0.619 & 0.563 & $\mathbf{0 . 7 4 4}$ & \\
\hline Ltt & 0.892 & 0.627 & 0.384 & 0.620 & 0.485 & 0.571 & 0.402 & $\mathbf{0 . 7 9 2}$ \\
\hline
\end{tabular}

To evaluate the reliability of the scale more closely, the author continues to analyze the composite reliability index
(CR) and the variance index AVE of the scales in the research. The results from Table 2 prove that the scales used by the author in this research meet enough reliability. The CR index of all the scales used is above 0.7 plus the AVE value of each scale is greater than 0.5 . Therefore, all of these scales are used to conduct further analysis, no components of the scale are excluded.

After verifying the scales, the author conducts SEM analysis. The analysis results show that $p$-value pcld affects ntld $(\mathrm{p}=0.00)$, cknv $(\mathrm{p}=0.00)$, hlnv $(\mathrm{p}=0.00)$, ltt $(\mathrm{p}=0.000)$ and cknv affects ltt $(\mathrm{p}) .=0.000)$ are all less than 0.05 , showing that the impact of pcld on the remaining factors in the model is statistically significant, and at the same time, the unnormalized regression coefficients between these variables are all greater than 0 , ie they are acting in the same direction, bearing a positive relationship with each other. However, the $p$-value of the unnormalized regression coefficients ntld affecting $\operatorname{ltt}(\mathrm{p}=0.296)$, hlnv affecting $\operatorname{ltt}(\mathrm{p}=0.388)$ is greater than 0.05 - this explains that the effect of ntld on ltt and hlnv are not statistically significant, hlnv (employee satisfaction), ntld (employee trust) have no influence on ltt (loyalty). Therefore, we have the results of hypothesis testing summarized in the table below:

TABle 4 Hypothesis test Results

\begin{tabular}{|l|l|l|}
\hline \multicolumn{1}{|c|}{ Hypothesis } & P-value & $\begin{array}{l}\text { Testing } \\
\text { result }\end{array}$ \\
\hline $\begin{array}{l}\text { H1: Empowerment leadership has a } \\
\text { positive effect on employee loyalty }\end{array}$ & $0.000<0.05$ & Accepted \\
\hline $\begin{array}{l}\text { H2: Empowerment leadership has a } \\
\text { positive influence on employees' } \\
\text { trust in leadership. }\end{array}$ & $0.000<0.05$ & Accepted \\
\hline $\begin{array}{l}\text { H3: Employee trust positively af- } \\
\text { fects employee loyalty. }\end{array}$ & $0.296>0.05$ & $\begin{array}{l}\text { Not } \\
\text { accepted }\end{array}$ \\
\hline $\begin{array}{l}\text { H4: Empowerment leadership has a } \\
\text { positive effect on employee com- } \\
\text { mitment. }\end{array}$ & $0.000<0.05$ & Accepted \\
\hline $\begin{array}{l}\text { H5: Employee commitment posi- } \\
\text { tively affects employee loyalty. }\end{array}$ & $0.000<0.05$ & Accepted \\
\hline $\begin{array}{l}\text { H6: Empowerment leadership has a } \\
\text { positive impact on employee satis- } \\
\text { faction. }\end{array}$ & $0.000<0.05$ & Accepted \\
\hline $\begin{array}{l}\text { H7: Employee satisfaction has a } \\
\text { positive impact on employee loy- } \\
\text { alty. }\end{array}$ & $0.388>0.05$ & $\begin{array}{l}\text { Not } \\
\text { accepted }\end{array}$ \\
\hline
\end{tabular}

This is a new finding in the research, from the table above it can be said that although the leadership style of empowerment has an impact on employees' trust and their satisfaction. However, the research object here is the business staff, whose paramount goal of business is always to make a profit, so trust in the leader or the satisfaction of subordinates. For superiors, it is not enough to make a business employee loyal to an organization, their loyalty is more dependent on salary, compensation or other factors that bring greater benefits to them. This is completely consistent with the specifics of the industry.

\section{Conclusion and Discussion}

In an open and integrated economy. Entities involved in business are facing perfect and extremely fierce competition. Many scholars have proved that the quality of human resources plays an important and not easily replaced role, to bring the victory of many businesses in those competi- 
tions. And what leaders should do for the company to grow is to be able to retain qualified and potential human resources. It can be said that the relationship between managers and employees or the leadership method of the administrator has a great influence on the creativity, dedication of employees or their attachment and loyalty. Many studies have been conducted to demonstrate this effect.

This research attempts to clarify the influence of anti-corruption on the quality of the relationship between managers and their subordinates and how the style of the leader affects the loyalty of subordinates. Specifically, the research tries to clarify the role of the empowerment leadership in the above relationships. Furthermore, this research also tries to examine the impact of relationship quality between leaders and subordinates on their loyalty. The results of the research indicate that the method of empowerment that managers use is a factor that has a strong impact on employee behavior. Specifically, this leadership method is considered as a criterion that makes employees create commitments to the business and it is also a factor that increases employee loyalty in the firm. In addition, this research also clarifies the quality of relationships between leadership and subordinates. In this research, the relationship quality mentioned here includes 3 factors, one is the trust of the employees in their leader, the other is the employee's satisfaction when working and working inside. organization and finally the commitments employees show to their organization. In particular, in this research, the author proves that the commitment of subordinates is a factor that plays an important role in the quality of the relationship between managers and employees. Therefore, in order to increase loyalty or other factors, leaders need to build a commitment and voluntary contribution to the business from their subordinates. At the same time, the results of data analysis also show that leaders empower employees as a basis on which managers can rely to maintain and strengthen the quality of relationships with employees. their subordinates - empowerment positively affects the trust, satisfaction or commitments they make. However, when the author examines the impact of relationship quality on employee loyalty, the analysis results show that trust or satisfaction that comes from empowerment leaders does not affect their loyalty. This is a new finding compared to previous research. The object of the author's survey is sales staff in the animal feed industry in Thanh Hoa, a characteristic of sales staff compared to other industries is that these people are very active, and the ultimate purpose of the activity. Business activity is always profit maximization, therefore, research explains that job satisfaction or employee trust is not enough to create loyalty for sales staff. This evidence contributes a part to the governance literature, providing new insights, providing a more complete approach than previous literature on the effects of power sharing. with employees on the quality of the relationship between superiors and subordinates and the impact of anti-corruption on the loyalty of subordinates.

Besides some theoretical contributions, the results of the research also have some practical contributions. To retain the core employees of the business, businesses should encourage their managers or leaders to delegate power to their employees, to give employees the decision of their duties,
Allowing and hearing from subordinates about decisions in the development of the business, giving them the right to comment on their own professional skills improvement programs or system decisions. The reward system they receive if they successfully complete the set goals, this makes employees feel that they have an important role inside the organization and the business they are dedicating always supports them in their career development. develop professional skills. This stimulates beneficial business behaviors such as creativity, self-control, total dedication and commitment and loyalty to the organization. Firms can rely on the scales of this research to develop a toolkit of leadership behaviors for their organization. Leaders' empowerment behaviors in this research were supportive of their subordinates' development, supporting their autonomy, or motivating them by providing related development opportunities. By empowerment they can make decisions, it also creates positive effects such as encouraging initiative and focusing on goals of employees.

Second, this document demonstrates that leader empowerment of their employees have a positive impact on the quality of relationships between superiors and subordinates, which in turn produces positive effects. Specifically, it is about building and maintaining employee commitments or trust and satisfaction. Using empowerment leadership strengthens and develops employee engagement within the framework of the research with a target audience of salespeople. Through this relationship, managers can propose appropriate methods and policies. Some behaviors suggested in this research are encouraging leaders and employees to share their feelings, leaders always care about employees, problems that their subordinates face at work, superiors have work instructions and always provide full benefits that their subordinates deserve while protecting their subordinates.

Firms can consider organizing more often mass organizations, commendation activities, cultural movements, physical training and sports, and volunteering activities. This creates opportunities for superiors and subordinates to improve their performance. improve relationship quality.

Finally, research shows that commitment behaviors of subordinates are strongly related to their loyalty. From here, managers can propose suitable options to increase employee commitment and loyalty through sharing power with their employees.

In addition to the contributions to research documents and practice, this topic still has some limitations as follows:

First, this research only surveyed people who are market workers in the feed sector in Thanh Hoa province, which makes the sample incomplete and not representative. Subsequent documents may consider expanding the survey area so that the sample is more general.

Second, this research proves only a few variables to have an impact on employee loyalty, future literature may consider examining the intermediaries between the relationship of employees and employees. leaders and employees in studies on leadership empowerment and employee loyalty.

In addition, future research can add factors to have a better overview of this field by adding some other research variables. The trust factor in the research being tested in this research is trust from subordinates in their superiors, trust is a factor with two-way effect, future research can test trust as 
an intermediary for empowerment leadership and employee motivation, in terms of employees gaining trust from managers, trust has a two-way effect, employees often reciprocate the trust of leaders. leadership by demonstrating a variety of positive behaviors such as dedication or increased commitment to the business.

Finally, in addition to the behavior of increasing engagement and commitment to the business, anti-corruption violence can cause many other impacts on employees in the organization such as satisfaction with the organization, stress, ability the employee's ability to succeed or the extent to which he or she contributes to the organization. Thus, subsequent scholars can contribute to the literature as well as practice by examining these areas.

\section{ACKNOWLEDGMENT}

We would like to express our gratitude for the support of Hanoi University of Industry as the Project No 42/2022.

\section{REFERENCES}

[1] L.-M. Tseng and J.-Y. Wu, "How can financial organizations improve employee loyalty? The effects of ethical leadership, psychological contract fulfillment and organizational identification," Leadership \& Organization Development Journal, 2017.

[2] B. Narteh and R. Odoom, "Does internal marketing influence employee loyalty? Evidence from the Ghanaian banking industry," Services Marketing Quarterly, vol. 36, pp. 112-135, 2015.

[3] G. M. Spreitzer, "Psychological empowerment in the workplace: Dimensions, measurement, and validation," Academy of management Journal, vol. 38, pp. 1442-1465, 1995.

[4] S. Hassan, R. Mahsud, G. Yukl, and G. E. Prussia, "Ethical and empowering leadership and leader effectiveness," Journal of Managerial Psychology, 2013.

[5] C.-M. Wu and T.-J. Chen, "Psychological contract fulfillment in the hotel workplace: Empowering leadership, knowledge exchange, and service performance," International Journal of Hospitality Management, vol. 48, pp. 27-38, 2015.

[6] S. L. Albrecht and M. Andreetta, "The influence of empowering leadership, empowerment and engagement on affective commitmen and turnover intentions in community health service workers: Test of a model," Leadership in health services, 2011

[7] S. Amundsen and Ø. L. Martinsen, "Self-other agreement in empowering leadership: Relationships with leader effectiveness an subordinates' job satisfaction and turnover intention," The Leadership Quarterly, vol. 25, pp. 784-800, 2014

[8] Y.-N. Cho, B. N. Rutherford, S. B. Friend, G. A. Hamwi, and J. Park, "The role of emotions on frontline employee turnover intentions," Journal of Marketing Theory and Practice, vol. 25, pp. 57-68, 2017.

[9] B. Buchanan, "Government managers, business executives, and organizational commitment," Public Administration Review, pp. 339347, 1974.

[10] B. P. Niehoff, R. H. Moorman, G. Blakely, and J. Fuller, "The influence of empowerment and job enrichment on employee loyalty in a downsizing environment," Group \& Organization Management vol. 26 , pp. 93-113, 2001

[11] H. Chen, "A comparative study of organisational commitment of bank employees in Ireland and China," 2009.

[12] P. Korkki, "The shifting definition of worker loyalty," New York Times, vol. 8, p. 8, 2011.

[13] S. Rajput, M. Singhal, and S. Tiwari, "Job satisfaction and employee loyalty: A study of academicians," Asian Journal of Management, vol. 7, pp. 105-109, 2016

[14] L. W. Porter, R. M. Steers, R. T. Mowday, and P. V. Boulian, "Organizational commitment, job satisfaction, and turnover among psychiatric technicians," Journal of applied psychology, vol. 59, p. 603, 1974

[15] R. Abdullah, M. Musa, H. Zahari, R. Rahman, and K. Khalid, "The study of employee satisfaction and its effects towards loyalty in hotel industry in Klang Valley, Malaysia," International Journal of Business and Social Science, vol. 2, pp. 147-155, 2011.

[16] J. W. Newstrom, K. Davis, and J. L. Pierce, "Organizational behavior: Human behavior at work," 1993.
[17] S. Arad, "Empowered work groups: Conceptual framework and empirical assessment of empowerment processes and outcomes in organizations," University of Illinois at Urbana-Champaign, 1994.

[18] M. H. Sadegh, M. A. Shah Hosseini, and A. Heidari, "Extracting the Effective Factors on Corporate Governance Formation in Strategic Alliances with Focus on International Joint Ventures through Systematic Literature Review," Journal of Business Management, vol. 12 , pp. $64-93,2020$

[19] S. Albers, B. Schweiger, and J. Gibb, "Complexity, power and timing in multipartner alliances: an integrative review and research agenda," Managing Multipartner Strategic Alliances. New York: Information Age Publishing, 2015.

[20] V. H. Villena, T. Y. Choi, and E. Revilla, "Revisiting interorganizational trust: is more always better or could more be worse?," Journal of Management, vol. 45, pp. 752-785, 2019.

[21] A. Alhaddad, "A structural model of the relationships between brand image, brand trust and brand loyalty," International Journal of Management Research and Reviews, vol. 5, p. 137, 2015.

[22] L. Bricci, A. Fragata, and J. Antunes, "The effects of trust, commitment and satisfaction on customer loyalty in the distribution sector," Journal of Economics, Business and Management, vol. 4, pp. $173-177,2016$

[23] S. T. Certo, J. R. Busenbark, H. s. Woo, and M. Semadeni, "Sample selection bias and Heckman models in strategic management research," Strategic Management Journal, vol. 37, pp. 2639-2657, 2016.

[24] Y. Choi, Y. Huang, and B. Sternquist, "The effects of the salesperson's characteristics on buyer-seller relationships," Journal of Business \& Industrial Marketing, 2015.

[25] R. M. Morgan and S. D. Hunt, "The commitment-trust theory of relationship marketing," Journal of marketing, vol. 58, pp. 20-38, 1994.

[26] A. Payne and P. Frow, "Relationship marketing: looking backwards towards the future," Journal of services marketing, 2017.

[27] M. G. Colombo and E. Piva, "Knowledge misappropriation risks and contractual complexity in entrepreneurial ventures' non-equity alliances," Small Business Economics, vol. 53, pp. 107-127, 2019.

[28] N. Q. Thu, T. T. Hoàng, H. K. Tân, and N. H. Sơn, "Hoạt động gọi vốn tài trợ khởi nghiệp từ cộng đồng: Tiếp cận từ lý thuyết marketing quan hệ," Tạp chi Nghiên cưu Kinh tế và Kinh doanh Châu Á, vol. 29, pp. 05-22, 2020.

[29] N. Huy, "Nâng cao chất lượng đội ngũ công chức chuyên môn cấp xã ở huyện Bố Trạch, tỉnh Quảng Bình," 2018.

[30] S. W. Wang, W. Ngamsiriudom, and C.-H. Hsieh, "Trust disposition, trust antecedents, trust, and behavioral intention," The Service Industries Journal, vol. 35, pp. 555-572, 2015.

[31] N. V. Thắng, "Hoàn thiện hoạt động quản trị nguồn nhân lực tại công ty trách nhiệm hữu hạn một thành viên Công trình Công cộng tỉnh Vĩnh Long," 2015.

[32] V. D. Bùi and T. H. Nguyễn, "Phát triển nguồn nhân lực logistics Việt Nam: Cần một chiến lược toàn diện," 2020.

[33] R. Bel, "Leadership and innovation: Learning from the best," Global business and organizational excellence, vol. 29, pp. 47-60, 2010.

[34] L. A. Halawi, J. E. Aronson, and R. V. McCarthy, "Resource-based view of knowledge management for competitive advantage," The electronic journal of knowledge management, vol. 3, p. 75, 2005.

[35] J. P. Meyer, D. R. Bobocel, and N. J. Allen, "Development of organizational commitment during the first year of employment: A longitudinal study of pre-and post-entry influences," Journal of management, vol. 17, pp. 717-733, 1991.

[36] T. M. Porter, "Making things quantitative," Science in context, vol. 7, pp. 389-407, 1994

[37] K. Do Duc, T. N. Anh, C. P. Duc, and T. H. Thanh, "Expanding fruit product market through brand, sales and distribution channel and product quality," Science and Technology Development Journal, vol. 17, pp. 6-19, 2014

[38] T. TIN and T. T Ó MT Ấ, "Mối quan hệ giữa cảm xúc với điểm đến và chất lượng quan hệ trong kinh doanh du lịch: Trường hợp du khách nội địa ở TP. Hồ Chí Minh," 2017.

[39] N. Kumar, L. K. Scheer, and J.-B. E. Steenkamp, "The effects of perceived interdependence on dealer attitudes," Journal of marketing research, vol. 32, pp. 348-356, 1995.

[40] M. Fiaz, Q. Su, and A. Saqib, "Leadership styles and employees' motivation: Perspective from an emerging economy," The Journal of Developing Areas, vol. 51, pp. 143-156, 2017.

[41] M. Cheong, F. J. Yammarino, S. D. Dionne, S. M. Spain, and C.-Y. Tsai, "A review of the effectiveness of empowering leadership," The Leadership Quarterly, vol. 30, pp. 34-58, 2019. 
[42] R. C. Mayer, J. H. Davis, and F. D. Schoorman, "An integrative model of organizational trust," Academy of management review, vol. 20, pp. 709-734, 1995.

[43] K. Dewettinck and M. Van Ameijde, "Linking leadership empowerment behaviour to employee attitudes and behavioural intentions: Testing the mediating role of psychological empowerment," Personnel Review, 2011.

[44] T. Bartram and G. Casimir, "The relationship between leadership and follower in-role performance and satisfaction with the leader: The mediating effects of empowerment and trust in the leader," Leadership \& Organization Development Journal, 2007.

[45] E. K. Kelloway, N. Turner, J. Barling, and C. Loughlin, "Transformational leadership and employee psychological wellbeing: The mediating role of employee trust in leadership," Work \& Stress, vol. 26, pp. 39-55, 2012.

[46] D. Lewicka, A. Glinska-Newes, D. Morrow, and J. Gorka, "The effect of job characteristics on employee loyalty: The mediation role of vertical trust and perceived supervisory support," Маркетинг $i$ менеджмент інновацій, pp. 168-185, 2018.

[47] M. Kim and T. A. Beehr, "Job crafting mediates how empowering leadership and employees' core self-evaluations predict favourable and unfavourable outcomes," European Journal of Work and Organizational Psychology, vol. 29, pp. 126-139, 2020.

[48] S. Allen, B. E. Winston, G. R. Tatone, and H. M. Crowson, "Exploring a model of servant leadership, empowerment, and commitment in nonprofit organizations," Nonprofit Management and Leadership, vol. 29, pp. 123-140, 2018.

[49] C. K. Sahoo, N. Behera, and S. K. Tripathy, "Employee empowerment and individual commitment: An analysis from integrative review of research," Employment Relations Record, vol. 10, pp. 40-56, 2010.

[50] M. Uzair, W. Razzaq, M. Sarfraz, and Q. A. Nisar, "Impact of HR practices on employee loyalty and commitment: Mediating role of job satisfaction," International Journal of Management Excellence, vol. 9, pp. 1067-1073, 2017.

[51] B. H. Janjua and A. Gulzar, "The impact of human resource practices on employee commitment and employee retention in telecom sector of Pakistan: Exploring the mediating role of employee loyalty," IOSR Journal of Business and Management, vol. 16, pp. 76-81, 2014.

[52] T. V. B. Hoàng and H. T. Hùng, "Các yếu tố ảnh hưởng đến mức độ hài lòng công việc của những người đã từng học tập hoặc làm việc ở nước ngoài-trường hợp nghiên cứu tại tỉnh thừa thiên huế," Hue University Journal of Science: Economics and Development, vol. 126, pp. 229-237-229-237, 2017.

[53] D. J. Weiss, R. V. Dawis, and G. W. England, "Manual for the Minnesota satisfaction questionnaire," Minnesota studies in vocational rehabilitation, 1967.

[54] J. Green, Job satisfaction of community college chairpersons: Virginia Polytechnic Institute and State University, 2000. 